\title{
ФЕНОМЕН ТВОРЧОСТІ МИРОСЛАВА СКОРИКА В КОНТЕКСТІ ОСВІТНЬО-ПРОФЕСІЙНИХ ПРОГРАМ $З$ МУЗИЧНОГО МИСТЕЦТВА
}

necessity, essence, practice]. Teacher's magazine. Available at://teacherjournal. in.ua/rozrobky/pedahohikaspivrobitnytstva-neobkhidnist-sutnist-praktyka. pp. 1-25. [in Ukrainian].

8. Pometun, O. I. (2007). Entsyklopediia interaktyvnoho navchannia [Encyclopedia of interactive learning]. Kyiv, p. 9. [in Ukrainian].

9. Rubinshteyn, S.L. (1999). Osnovy obshchey psikhologii [Fundamentals of general psychology]. St.Peterburg, 720 p. [in Russian].

10. Natsionalna stratehiia rozvytku osvity v Ukraini na period do 2021 roku [National strategy for the development of education in Ukraine until 2021]. Available at: akon5.rada.gov.ua/laws/show/344/2013. [in Ukrainian].

11. Iakymanskaia, Y.S. (2000). Tekhnolohyia lychnostno oryentyrovannoho obuchenyia [Technology of personality-oriented learning]. Moscov, 176 p. [in Russian].

12. Vyshkivska, V., Shykyrynska, O. \& Malinka, O. (2021). Educational robotics as a means of basic learning skills of younger students. Innovative Approaches to Ensuring the Quality of Education, Scientific Research and Technological Processes. Publishing House of University of Technology, Katowice, pp.323-330. [in Englisn].

Стаття надійшла до редакції 18.08.2021

УДК 78.071.1(77):78.071.5

DOI:

Юрій Попов, кандидат мистецтвознавства, доцент, доцент кафедри спеціального фортепіано Харківського національного університету мистецтв імені І. П. Котляревського Марія Ярко, кандидат мистеитвознавства, доиент, дочент кафедри музикознавства та фортепіано Дрогобииького державного педагогічного університету імені Івана Франка

\section{ФЕНОМЕН ТВОРЧОСТІ МИРОСЛАВА СКОРИКА В КОНТЕКСТІ ОСВІТНЬО- ПРОФЕСІЙНИХ ПРОГРАМ З МУЗИЧНОГО МИСТЕЦТВА}

У статті стверджується унікальність освітньої ролі творчої спадщини Мирослава Скорика, оскільки нею заявлено активну співучасть у стильовій панорамі усього ХХ па початку ХХІст.: вона охоплює множину стильових інваріантів, з-поміж яких особливе місце займають етнонаціональна координата творчості, неостильові форманти Модернізму і апробачія так званого ейдетичного стилю. Усе ие - підстава для герменевтичної рецепції його творчості у світовому контексті, щяо забезпечуватиме інтегрування інформаційного поля з історії музики, а також достеменного розуміння індивідуально-стильового дискурсу творів композитора задля вірогідної виконавської інтерпретації.

Ключові слова: Мирослав Скорик; стильові дискурси музичної творчості; інтегровані навчальні повідомлення.

Jim. 7.

Yuri Popov, Ph.D.(Art Studies), Associate Professor of the Special Piano Department, Kharkiv Ivan Kotlyarevskiy National University of the Arts

Maria Yarko, Ph.D.(Art Studies), Associate Professor, Associate Professor of the Musicology and Piano Department Drohobych Ivan Franko State Pedagogical University

\section{THE PHENOMENON OF MYROSLAV SKORYK'S CREATIVITY IN THE CONTEXT OF EDUCATIONALAND PROFESSIONAL PROGRAMS IN THE MUSIC ART}

The article asserts the uniqueness of the cultural and educational role of Myroslav Skoryk context of musical legacy; it represents the author's active participation in the stylistic panorama of the whole $20^{\text {th }}$ the early $21^{\text {st }}$ century and thus provides an opportunity to view various stylistic invariants in an integrated way. After all, Myroslav Skoryk's works encompass many stylistic invariants, among which a special place is occupied by the ethno-national coordinate of music, neo-style forms of Modernism (neoclassicism, neo-baroque, neo-romanticism, and neo-folklore). Moreover, in the last period of his life the composer was able to create his music in the postmodernist spirit, exhibiting the so-called "eidetic" style. All this allows us to formulate sound judgments about the stylistic phenomena of modern times; in particular - in the discourse of stylistic parallels in the world context. On the one hand, such position provides an opportunity to see the so-called "stylistic allusions" (a kind of indirect quote, a hint); on the other hand, to thoroughly build up a discourse of cognition of the individual stylistic character of the composer's assimilation of various stylistic invariants. It is also stated that the described features of the very "vision" of stylistic and genre character in the work of Myroslav Skoryk become important in modeling educational messages, maximally synthesized, generative and integrated in relation to the above contexts. This will help determine the importance of 


\section{ФЕНОМЕН ТВОРЧОСТІ МИРОСЛАВА СКОРИКА В КОНТЕКСТІ ОСВІТНЬО-ПРОФЕСІЙНИХПРОГРАМ З МУЗИЧНОГО МИСТЕЦТВА}

a methodologically plausible understanding of the individual style of the composer, the technologies he uses to create musical themes, etc.; in particular, it will ensure the integration of the information sphere on the history of music, which is extremely important for understanding the individual stylistic discourse of the composer's works for the sake of credible interpretation during performance. In turn, it should be noted that so called "iconic" works of Myroslav Skoryk were selected for consideration, which have been systematized according to the genre. But at the same time, attention is paid to the characteristics of the composer's musical thinking technologies in terms of genre modifications and stylistic qualities of musical themes. On this basis, it is concluded that Myroslav Skoryk's World of Music is a phenomenon that in many stylistic and genre discourses will reliably shape the musical consciousness of modern musicians and the historical memory of the national culture.

Keywords: Myroslav Skoryk; stylistic discourses of music composition; integrated educational messages.

П остановка проблеми. Методологічні принципи сучасних педагогічних технологій закликають до інтегрованого підходу у формуванні предметного змісту навчальних дисциплін, а також - осягнення результатів з виховання рефлексивної культури особистості. Така установка має колосальне значення для корекції змісту освітньо-професійних програм з музичного мистецтва та методів викладання музичних дисциплін у намірі знаходження властивих дискурсів їх предметного змісту. 3-поміж таких, наприклад, - семантичний та герменевтичний аналіз музичної творчості, що становлять собою певного роду конгломерат і тим самим здатні забезпечувати глибинне розуміння суті творчого задуму, його ідеї та засобів їх втілення. Натомість на практиці мають місце усталені стереотипи зразка автобіографічного та морфологічного підходів, що з точки зору сучасної методології хибують “констатацією” і шаблонами формально-логічного підходу (на рівні “правила”). Поміж тим, Світ музики та його втілення у кожному конкретному музичному творінні не припускае “шаблонів": кожен з них унікальним (одиничним) втіленням того загального, що зветься Абсолютом і трансформується в зоні особливого (“духовна ситуація часу”, стиль епохи, композиторська школа). А отже, суть розв'язання проблеми становить методологічно вивірене тлумачення музичних явищ у належних понятійних формах та методичних принципах,

Аналіз основних досліджень і публікацій. Джерельна база 3 дослідження творчості Мирослава Скорика $\epsilon$, здавалося б, доволі багатою: поява публікацій, присвячених дослідженню його творів зазвичай була миттєвою реакцією на їх уже першу презентацію. Більше того, музикознавці буквально випереджували час, подаючи спроби витворення "цілісного" образу композитора, хоча творче й, власне, стильове амплуа його творчості постійно змінювалося. Відзначимо, отже, найбільш грунтовну працю 3 дослідження творчості Мирослава Скорика, про яку вже можна було говорити, так би мовити, 3 віддалі часу: це - монографія Любові Кияновської "Мирослав Скорик: творчий портрет композитора в дзеркалі епохи" [3], якою охоплено максимальну кількість творів різного стильового гатунку і в повноті іх жанрових форм (відомо про продовження автором самої монографії вже на матеріалі творчості останніх років життя композитора). До цінних здобутків цієї ж дослідниці належить також низка $\dddot{11}$ статей про методи музичного мислення композитора. Так, у цих матеріалах (від 1998 до 2001 р.) ставиться питання про принципи стильової гри у творчості Мирослава Скорика [4]), поєднано параметри осмислення особистості композитора як “людини і митця" [2] тощо. Слід, щоправда, згадати ще про фактично унікальні дослідницькі розробки, де ставляться вельми важливі для зрозуміння творчості Скорика питання: наприклад, щодо природитаісторичноїфункціійогогстилю(В.Задерацький, 1999); семантичної спрямованості оновлення деяких традиційних форм (Е. Гончар, 1991); образного змісту фортепіанних концертів (Г. Блажкевич, 1999); принципів втілення карпатського фольклору в струнних ансамблях (Є. Дзюпина, 1982). Тобто, ще 60-х pp. ХХ ст. й до сьогодні творчість Мирослава Скорика немов “шукає” собі властиву аналітичну парадигму стильового аналізу та їі провідну ідею.

Мета статті - віднайти провідну ідею творчості Мирослава Скорика як активного учасника в складанні стильової панорами др. пол. $\mathrm{XX}$ - поч. XXI ст., що мало б здатність долучитися до змістової корекції освітньо-професійних програм з музичного мистецтва.

Виклад основного матеріалу. Як уже згадувалося, на сьогодні освітньо-професійні програми 3 музичного мистецтва окремішним порядком містять виклад інформації автобіографічного роду, а стосовно аналізу музичного матеріалу обмежуються констатацією формально-логічних значень так званої "музичної форми" - поза методикою аналізу композиційно-драматургічної логіки. Ще гіршою $є$ ситуація з визначенням жанру: його шаблоном висувається певне "правило" щодо кількості частин та виконавського ресурсу, а не "типу змісту". Та й щодо стилю тенденційно продовжується маневр пошуку “рис стилю", а не його ментальних (металогічних) 


\section{ФЕНОМЕН ТВОРЧОСТІ МИРОСЛАВА СКОРИКА В КОНТЕКСТІ ОСВІТНЬО-ПРОФЕСІЙНИХПРОГРАМ З МУЗИЧНОГО МИСТЕЦТВА}

значень; у тому числі - суб'єктивного досвіду світовідчуття як основи індивідуального композиторського стилю.

Викладеними вказівками на недоліки стверджується, що узвичаєні стереотипи аж ніяк “не впораються" з вельми непростим для зрозуміння стильовим та жанрово-стильовим проєктуванням творів Мирослава Скорика. А отже, для “виправлення” ситуації пропонуємо низку аналітичних етюдів, в яких, з одного боку втілено намір достеменного тлумачення стильових якостей твору; з іншого - представлено модель тлумачення творчості композитора у складі панорами стильових явищ новітньої музики взагалі. При цьому також спеціальним чином планується вказування на більш-менш очевидні стильові алюзії - “натяки” на певний стильовий інваріант.

У числі таких прикладів вирішено спершу подати тлумачний аналіз фортепіанних “Варіацій”. Але спершу - короткий аналітичний екскурс в історію варіаційної форми. Як стверджує $€$. Назайкінський, витоками варіаційної композиційної форми є народне інструментальне мистецтво; але власне імпровізації покладаються на “пошук теми" і тому власне “варіації” первинно вважаються “не композиційної природи” [6, 1617]. Натомість, веде далі мову дослідник, класичні версії варіацій здобули нормою первинність представлення теми - обов'язково синтетичної на склад інтонаційної моделі, - і подальше “вичерпування” іiі інтонаційних значень з метою їі переінтонування та трансформацію у щоразу інший склад тематизму [там само]. Однак у XX ст. - зокрема у творчості Мирослава Скорика,внаслідок сформування “звукових ідей новітнього музичного мистецтва” (В. Кавецька, М. Ярко [1]) та “модерністського канону звукомислення ([7]) суттєво змінився підхід до структурування варіацій; а надто - типів варіювання. Так, у Скорика “варіювання “теми” (власне “варіаціі”) передусім здійснюються засобом її регістровотембральних перетворень. Суттєві виразові зрушення творять також темпові зрушення (...), що разом зі зміною фактурного опрацювання інтонаційного рельєфу “теми” свідчать про рух образного змісту за типом “характерних" [7, 25]. Усе, відтак, вказує на спосіб творення так званого “жанрового” тематизму; але з кожною наступною варіацією власне жанрова характеристичність нейтралізується: “кожна варіація має власний стиль та виконавський характер - більшою мірою зумовлений самим “музикуванням" [7, 26]. Важливо також відзначити доволі очевидну “інтегрованість” мислення композитора: “...поєднувані структури й функції (тут драматургічні Ю. П.) упорядковуються на кожному організаційному рівні, забезпечуючи тим самим ефект відновлення (лат. integration поповнення, відновлення)" [7, 30]. Відзначимо також вагомість тотального дотримання сонористичної манери як техніки композиторського письма, що свідчить про авангардну стильову характерність звукових ідей твору. Крім того, розглянутий твір доводить справедливість судження музикознавців, що загально варіаціям властиві такі модальності, як “оповідність та рефлексії, що свідчить про їх наративну (власне оповідну) природу як семантичного інваріанту або ж семантеми" [7, 32]. Більше того, “Варіації” Скорика - це зразок неореставрації традицій “концертних” варіацій, тобто $\epsilon$ образком неокласичного типу компонування: “. .. важливою умовою специфікації тематизму (такої необхідної й властивої для неостильового поєктування) постають темброворегістрові переінтонувння та тембро-фактурні перевтілення, темброво-акустичні (гармонікофонічні) перетворення й темброво-артикуляційні трансформаціі”' [7, 33]. І ще один висновок: Скорик увиразнив семантику варіацій як типу структури - сонорні “проростання" звукової тканини забезпечили ідентичність варіаційному інваріанту; своєю чергою, їх процесування забезпечило “класичну” композиційну логіку власне варіацій.

Ще більш виразні ознаки стильової характерності у творчості Мирослава Скорика містять у собі численні “сольні” Концерти (Концерт № 1 для скрипки 3 оркестром, “Юнацький” концерт для фортепіано з оркестром; концертна дилогія 80-х років, Концерт № 2 для скрипки і симфонічного оркестру, Концерт № 3 для фортепіано, струнного оркестру та великого барабана та ін.) репрезентують множину стильових інваріантів. Передусім - в модальності неоромантизму (реінтерпретація інваріанту “концерту-монологу”), а також у модальності “викликів постмодерну”. Загально ж охоплювані стильові системи немов ведуть композитора лабіринтом “маскараду неостилів”. Зокрема, доволі очевидно заявлено неореставрацію барокової моделі концерту з іiі “примхливим" духом концертування. До того ж ця модель оснащена прихильністю композитора до структури так званої суцільно-циклічної композиційної форми (інша назва - контрастно-складова), яка первинно належить добі Бароко, але є активно залучуваною у XX ст. (наприклад - у камерних кантатах). Специфіка цієї композиційної форми й надає композиторові можливість увиразнювати параболічний тип драматургічного співвідношення 


\section{ФЕНОМЕН ТВОРЧОСТІ МИРОСЛАВА СКОРИКА В КОНТЕКСТІ ОСВІТНЬО-ПРОФЕСІЙНИХ ПРОГРАМЗ МУЗИЧНОГО МИСТЕЦТВА}

сегментів концепції - із різкими зсувамизрушеннями у вираженні (Л. Кияновська трактує цей прийом як “гру” контрастами за “законом випадковості" [3, 178]).

Своєю чергою, відзначимо, що упродовж творчості Мирослав Скорик виявив чітку незалежність від будь-яких стереотипів і при цьому - неймовірну гнучкість у змінах у стильових амплуа. А ще вартий зауваги той факт, що композитор вельми часто творить узагальнення змістовних значень засобом певного жанрового інваріанту: наприклад - Токата, Речитатив, Інтермецо тощо.

Так, його опера “Мойсей” має виразні ознаки ораторіальності, що значить переймання семантики жанру ораторії як “знаку” (семантеми) тлумачення істинного.

Своєю чергою, “Партити” Мирослава Скорика (відомо про шість партит - № 1 для струнного оркестру, № 2 для камерного оркестру, № 3 для струнного квартету, № 4 для великого симфонічного оркестру, № 5 для фортепіано, № 6 для струнного квартету та у версії для камерного оркестру) - це кожного разу інша стильова модель, якими композитор немов “доповнює” ідентичність історико-стильового “портрету” цієї жанрової форми. Нагадаємо, що власне партита віддавна мислилась як інструментальна музика світського плану. А отже, не будучи пов'язаною 3 церковним середовищем (як, наприклад, їй історично одночасна "церковна соната") була покликана демонструвати певну “стильову вишуканість”. Додамо також, що жанрова форми партити (витоки іiі історії сягають доби Відродження) традиційно мислилась як добірка п’єс. Їх послідовність, щоправда, не надавала враження певного цілого - такого, яке в подальшому ході історії музики осягнула така жанрова форма, як “сюїта” (букв. - ряд, низка). Поза тим, старовинна партита - це вповні конкретний спосіб типізації тематичного матеріалу, за яким закріплено темпові та композиційні пріоритети, що при домінуванні “предметності” танцювально-побутового жанру розвивали ідею зіставлення складових частин за принципом неконфліктного (недраматичного) контрастування. А отже, зацікавленість Мирослава Скорика прадавньою жанровою формою знову ж таки свідчить про намір неокласичного стильового проєктування; причому власне “образ" прадавньої “партити” надав простір для майже театралізовано характеристичного (за принципом програмності) вираження. Примітними, зокрема, є жанрові позначення частин партит (Прелюдія, Токата,
Фуга, Речитатив, Антифони, Quasi valse, Capriccio, Postludium, Арія, Фінал, Пасакалія, Рондо) та цілком абстрактні алюзії (Остінато, Pastorale, Звучання, Ритм, Хор, Контрасти). І кожного разу - це і конденсоване інтонаційне моделювання, $\mathrm{i}$ активні інтонаційно-образні трансформації.

Услід за тим надамо аналітичні спостереження за тими творами Мирослава Скорика, які уповні справедливо (попри відсутність у його творчості жанру симфонії) розглядати саме як “симфонічну музику": це - “Гуцульський триптих" або "Гуцульська симфонієтта" та Концерт для оркестру (“Карпатський”). Перший надає можливість прицільно розглядати концептуальні виміри; інший - жанрово-стильові паралелі та особливості композиційної форми; але обидва мають спільним орієнтування на принцип програмності, що консолідується довкола унікального сонористичного комплексу “звукових ідей”.

Варто, мабуть, нагадати: “Гуцульський триптих”, що має подвійну назву, як “Гуцульська симфонієта" був укладений композитором на основі музики до кінофільму “Тіні забутих предків" (за Михайлом Коцюбинським); і це надає можливість “пам'ятати” візуальний ряд та його характерність, що їх створив режисер цього кінофільму Сергій Параджанов. Своєю чергою, у “триптиху” Мирослав Скорик објєднав символіку літературного першоджерела та режисерського задуму у цілісну концепцію, що має сегментами “опис": дитинства Івана та Марічки; їхнього палкого кохання та зловісно-містичний образ Чугайстра (смерть Івана). Зокрема, тематизм твору якнайточніше передає символіку духовноетичних і містичних значень літературного першоджерела, а також незвичність режисерської роботи: “нагадування”, вкраплення деталей з їх смисловим відтінком, зіставленням містичного 3 божественним тощо. Звідси - витоки аналітичного опрацювання твору, яке, згідно 3 вимогами обсягу статті, ми свідомо оминаємо, аби перейти до згадки про чи не найгеніальніший творчий проєкт Мирослава Скорика - Концерт для оркестру (“Карпатський”).

Разом із "Гуцульським триптихом" Концерт для оркестру (“Карпатський”) творять осібну лінію стильового базису творчості Мирослава Скорика - неофольклористичну, про що в радянські часи говорили як про “нову фольклорну хвилю”: цей стильовий напрям визначив прийом концептуалізації засобом “фольклорної фонеми” (вислів Євгена Станковича). Однак власне сам концерт “для оркестру” висвічує ще одну стильову лінію - необарокову, відроджуючи 


\section{ФЕНОМЕН ТВОРЧОСТІ МИРОСЛАВАСКОРИКА В КОНТЕКСТІ ОСВІТНЬО-ПРОФЕСІЙНИХ ПРОГРАМ З МУЗИЧНОГО МИСТЕЦТВА}

модель “кончерто гроссо”. А тому найважливішим є виразне відтворення "духу коцертності" ефектного представлення виконавської вправності, коли ідея "змагання" та “концертування" стосується кожної оркестрової групи й навіть окремого учасника оркестру як змагання “з самим собою". Ще одна важлива стильова лінія цього твору Скорика - це сонористична манера письма, що суголосить сонористиці як авангардній технології творення музичної матерії: “звукові блоки” та “плями” із секундових “грон”, ефектні тембральні вкраплення тощо. Загалом же увесь цей Концерт - це “концерт” колористики, розмаїтих образних асоціацій з народним інструментальним музикуванням та коломийкою, урбаністикою, звуковими імітаціями трембіт, цимбал тощо. Інакше кажучи, образну програму твору конкретизують темброво-смислові узагальнення або ж радше темброво-акустичні явища, що пов'язані не лише з фольклорними першоджерелами (коломийка, трембітання, троїсті музики), але передусім із світовідчуттєвим модусом національних героїв й таємничим колоритом Карпатського ландшафту. У підсумок ствердимо: стильові якості Концерту для оркестру (“Карпатський”) забезпечує гнучке переплетення барокових форм концертування та фольклорної моделі музикування зії варіантністю й енергетичними константами зразка інструментального речитативу.

Висновки 3 даного дослідження i перспективи подальших розвідок у даному напрямку. У ході дослідження виявлено передусім високу міру інтегрованості авторської системи Мирослава Скорика, що надає можливість активно залучати увесь його творчий актив до освітньо-професійних програм 3 музичного мистецтва. У їх контексті творчість цього геніального композитора повинна поєднуватися з навчальними повідомленнями про композиторів інших країн; передусім - Пауля Гіндеміта та Арнольда Шенберга, Ігоря Стравинського і Сергія Прокоф'єва, з творчістю яких музика Мирослава Скорика єднається на тлі неокласичного спрямування творчості. Своєю чергою, як виразного “неофольклориста" композитора Мирослава Скорика необхідно розглядати разом із таким видатним неофольклористом, як Бела Барток. Цей перелік “паралелей” поміж композиторами різних країн, що заразом створювали модерністичний напрям музичної творчості 3 його неостильовими “формантами” можна (й потрібно!) розвивати. Бо саме тоді й виявиться феномен творчості Мирослава Скорика - його унікальна роль у корекції предметного змісту освітньо-професійних програм з музичного мистецтва (історія музики, інструментальне виконавство тощо). Подальші розвідки у накресленому напрямі покликані безпосередньо конкретизувати як “стильові паралелі”, так і глибинне осмислення стильових процесів усього XX ст. та початку XXI як симбіозу стильових інваріантів.

\section{ЛІТЕРАТУРА}

1. Кавецька В., Ярко М. Звукові ідеї новітнього музичного мистецтва: на матеріалі концертної програми “Авангардна (і не тільки) фортепіанна музика XX ст.” у виконанні О. Струлецької та С. Позднишевої. Молодь і ринок. № 3 (146) березень 2017. С. 26-30.

2. Кияновська Л. Мирослав Скорик: людина i митець. Львів : Незалежний культурологічний журнал “Ї”, 2008. С. 591.

3. Кияновська Л. Мирослав Скорик: творчий портрет композитора в дзеркалі епохи : монографія. Львів : Сполом, 1998. 208 с.

4. Кияновська Л. Принципи стильової гри у творчості М. Скорика. Науковий вісник НМАУ імені П. І. Чайковського. Вип. 10 : Мирослав Скорик (до 60-річчя від дня народження композитора). Київ., 2000. С. 15 - 23.

5. Кияновська Л. Українська музична культура 60-х рр. Українаська музична культура: навчальний посібник. Львів : “Тріада плюс”, 2009. С. 218-264.

6. Назайкинский Е. Логика музыкальной композиции : монография. Москва: Музыка, 1982. $319 \mathrm{c}$.

7. Ярко М. Фортепіанні “Варіації” М. Скорика в контексті модерністського канону звукомислення та модерного характеру національного стилеутворення (з нотним додатком) : науковопопулярне видання. Редакційно-видавничий відділ Дрогобицького державного педагогічного університету імені Івана Франка, 2009. 50 с.

\section{REFERENCES}

1. Kavetskaya, V. \& Yarko, M. (2017). Zvukovi ideyi novitnioho muzychnoho mystetstva: na materiali kontsertnoyi prohramy "Avanhardna (i ne tilky) fortepianna muzyka KHKH st." u vykonanni O. Striletskoyi ta S. Pozdnyshevoyi [Sound ideas of modern musical art: on the material of the concert program "The avant-garde (and not only) piano music of the twentieth century", performers O. Striletska and S. Pozdnysheva]. Youth \& market. Issue 3 (146) March 2017. pp. 26-30. [in Ukrainian].

2. Kyianovska, L. \& Kyyanovska, L. (2008). Myroslav Skoryk: liudyna i mytets [Myroslav Skoryk: a man and an artist]. Lviv, 591 p. [in Ukrainian]. 
3. Kyianovska, L. (1998). Myroslav Skoryk: tvorchyy portret kompozytora $\mathrm{v}$ dzerkali epokhy [Myroslav Skoryk: a creative portrait of the composer in the mirror of the era]. Monograph. Lviv, 208 p. [in Ukrainian].

4. Kyianovska, L. (2000). Pryntsypy styliovoyi hry u tvorchosti M. Skoryka [The principles of stylistic play in the works of M. Skoryk]. Scientific Bulletin of P.I. Tchaikovsky NMAU. Issue. 10. Kyiv, pp. 1523. [in Ukrainian].

5. Kyianovska, L. (2009). Ukrayinska muzychna kultura 60-kh rr. [Ukrainian musical culture of the 1960]. Ukrainian musical culture: textbook. Lviv, pp. 218-264. [in Ukrainian].
6. Nazaykynskyi, E. (1982). Logika muzykalnoy kompozitsii [The logic of musical composition]. Monograph. Moscow, 319 p. [in Ukrainian].

7. Yarko, M. (2009). Fortepianni "Variatsiyi" M. Skoryka v konteksti modernistskoho kanonu zvukomyslennya ta modernoho kharakteru natsionalnoho styleutvorennya [Piano "Variations" by M. Skoryk in the context of the modernist canon of sound interpretation and the modern character of national style formation]. (with musical notation): popular edition. Publishing Department of Ivan Franko State Pedagogical University in Drohobych, 50 p. [in Ukrainian].

Стаття надійшла до редакції 12.08.2021

УДК 378.011.3-051:005.336.2

DOI:

Лілія Стахів, кандидат педагогічних наук, доиент, завідувач кафедри педагогіки та методики початкової освіти Дрогобицького державного педагогічного університету імені Івана Франка Василь Стахів, кандидат біологічних наук, дочент кафедри біології та хіміі Дрогобицького державного педагогічного університету імені Івана Франка Сузанна Волошин, кандидат педагогічних наук, старший викладач кафедри біології та хімї Дрогобииького державного педагогічного університету імені Івана Франка

\section{ФОРМУВАННЯ КРЕАТИВНИХ КОМПЕТЕНТНОСТЕЙ МАЙБУТНЬОГО ВЧИТЕЛЯ ЗАКЛАДІВ ЗАГАЛЬНОЇ СЕРЕДНЬОЇ ОСВІТИ В УМОВАХ МОДЕРНІЗАЦІЇ ВИЩОї ШКОЛИ}

У статті проаналізовано проблему формування креативних компетентностей майбутнього вчителя закладів загальної середньої освіти в умовах модернізації вищої школи; подано поняття "креативність", “креативна компетентність”, “креативний учитель”, “креативне мислення”, “креативна педагогічна діяльність”; акиентовано увагу на оптимальному поєднанні різних форм та методів навчання під час викладання навчальних дисциилін педагогічного, природничого ичиклу та фахових методик у закладах вищоі освіти.

Ключові слова: креативність; компетентність; креативні компетентності; заклади загальної середньої освіти; заклади вищої освіти; модернізація; модернізація вищої иколи.

Jim. 8.

Liliya Stakhiv, Ph.D.(Pedagogy), Associate Professor, Head of the Pedagogy and Methods of Primary Education Department Drohobych Ivan Franko State Pedagogical University

Vasyl Stakhiv, Ph.D.(Biology), Associate Professor of the Biology and Chemistry Department Drohobych Ivan Franko State Pedagogical University

Suzanna Voloshin, Ph.D.(Pedagogy), Senior Lecturer of the Biology and Chemistry Department Drohobych Ivan Franko State Pedagogical University

\section{FORMATION OF CREATIVE COMPETENCIES OF THE FUTURE TEACHER IN INSTITUTIONS OF GENERAL SECONDARY EDUCATION IN THE CONDITIONS OF MODERNIZATION IN HIGHER EDUCATION}

The article analyzes the problem of forming a creative competencies of the future teacher in general secondary education in the modernization of higher education; the concepts of "creativity", "creative competence", "creative teacher", "creative thinking", "creative pedagogical activity" are presented. The issue of forming a creative competencies necessary for the future professional activity of teachers in general secondary education institutions 